\title{
Obtaining of ZnSe nanocrystals from ZnSe bulk crystals by mechanical milling and chemical vapor deposition in silica matrices
}

\author{
L.I.Voloshina, V.V.Seminko, I.I.Bespalova, \\ P.O.Maksimchuk, O.G.Viagin, A.A.Masalov \\ Institute for Scintillation Materials, STC "Institute for Single Crystals", \\ National Academy of Sciences of Ukraine, \\ 60 Nauky Ave., 61001 Kharkiv, Ukraine
}

Received October 27, 2016

In the paper ZnSe nanocrystals were obtained from bulk ZnSe crystal using two different methods: mechanical milling and heating of bulk crystal with subsequent deposition of zinc and selenium in the pores of silica matrix. Both samples demonstrate wellknown for ZnSe bulk crystals luminescence band at $~ 500 \mathrm{~nm}$, however its temperature stability is sufficiently higher for nanocrystals obtained by either of two routes than for correspondent bulk sample. Beyond ZnSe luminescence, sample obtained by mechanical milling show $\mathrm{ZnO}$ luminescence determined by $\mathrm{ZnO}$ layer formed at the surface of $\mathrm{ZnSe}$ nanocrystal in oxidative atmosphere.

Keywords: ZnSe nanocrystals, luminescence.

Исследованы нанокристаллы ZnSe, полученные из объемного кристалла ZnSe при помощи двух методов: механического размола и нагревания объемного кристалла с последующим осаждением цинка и селена в порах матрицы диоксида кремния. Оба образца демонстрируют хорошо известную для объемного кристалла ZnSe полосу люминесценции при $\sim 500$ нм, однако ее температурная стабильность существенно выше для нанокристаллов, полученных каким-либо из двух методов, чем для соответствующих объемных материалов. Помимо люминесценции $\mathrm{ZnSe}$, образец, полученный механическим размолом, демонстрирует люминесценцию $\mathrm{ZnO}$, причиной которой является наличие слоя $\mathrm{ZnO}$, который формируется на поверхности нанокристалла ZnSe в окислительной атмосфере.

Отримання нанокристалів ZnSe з об'ємних кристалів ZnSe за допомогою механічного розмолу $\mathbf{i}$ хімічного осадження 3 парової фази у матрицях діоксиду кремнію. Л.І.Волошина, В.В.Селінько, І.І.Беспалова, П.О.Максилчук, О.Г.Вягин, А.О.Масалов.

Досліджено нанокристали ZnSe, що отримані з об'ємного кристала ZnSe за допомогою двох методів: механічного розмолу і нагрівання об'ємного кристала з подальшим осадженням цинку і селену у порах матриці діоксиду кремнію. Обидва зразки демонструють добре відому для об’ємного кристала ZnSe смугу люмінесценції 500 нм, проте іï температурна стабільність істотно вища для нанокристалів, отриманих будьяким із двох методів, ніж для відповідних об'ємних матеріалів. Крім люмінесценції $\mathrm{ZnSe}$, зразок, отриманий механічним розмолом, демонструє люмінесценцію ZnO, причиною якої є наявність шару ZnO, який формується на поверхні нанокрістала ZnSe в окислювальному середовищі. 


\section{Introduction}

Semiconductor $A^{l l} B^{V I}$ nanocrystals (such as $\mathrm{ZnSe}, \mathrm{CdSe}, \mathrm{ZnS}$ and CdS) recently have drawn a lot of attention as perspective materials for development of solar cells [1-3], lasers and displays [4-7], and fluorescent probes for detection of biological objects at multi-parameter medical diagnostics [8-11]. Such a wide range of applications of these materials is determined first of all by their size-dependent electronic properties, namely by strong size dependence of their band gap width allowing obtaining of nanostructured materials with tunable emission [4, 7]. Modification of the surfaces of $A^{\prime l} B \mathrm{Vl}$ nanocrystals by organic molecules [12] or their incorporation into semiconductors with larger band gaps [13] allows obtaining bright and stable luminophors for the wide range of practical applications.

Luminescence characteristics of both $\mathrm{A}^{\mathrm{ll}} \mathrm{B} \mathrm{VI}$ bulk crystals and nanocrystals are dependent on their method of preparation and treatment as well. Presence of cationic and anionic vacancies, interstitials, and surface defects of various kinds are the factors which can drastically change the optical properties of $\mathrm{A}^{\mathrm{Il}} \mathrm{B} \mathrm{Vl}$ materials.

In our paper we have used two different methods of ZnSe nanocrystals obtaining from corresponding bulk crystal: first one was the mechanical milling of bulk ZnSe crystal and second one - the heating of bulk crystal with subsequent deposition of zinc and selenium in the pores of silica matrix. The role of $\mathrm{SiO}_{2}$ template was two-fold: as a substrate for deposition of ZnSe from the vapor phase and for restriction of the ultimate size of resulting nanocrystals by the size of the pore. As turned out, both samples demonstrate unexpected temperature stability of donor-acceptor luminescence at $\sim 500 \mathrm{~nm}$ making possible use of these materials for a number of applications in luminescent techniques.

\section{Experimental}

ZnSe nanocrystals were obtained from ZnSe bulk crystal grown by chemical vapor deposition (CVD) method using two different routes - namely, by mechanical milling of bulk crystal and by heating of bulk crystal in the furnace tube with subsequent deposition in the pores of silica matrix.

ZnSe powder $(2.5 \mathrm{~g})$ obtained after milling of ZnSe (CVD) crystal was placed in an agate mortar with $5 \mathrm{ml}$ of $n$-heptane. After milling the resulting paste was placed into a measuring cylinder with ground-based plas- tic cap on the volume to $25 \mathrm{ml}$ and the treatment was performed in an ultrasonic bath for $10 \mathrm{~min}$. Thereafter, the cylinder was refilled with $n$-heptane to $15 \mathrm{ml}$ mark and sedimentation of resulting solution was realized during $48 \mathrm{~h}$.

$\mathrm{SiO}_{2}$ matrices were synthesized according to the method described in [14]. To $3.15 \mathrm{ml}$ of methanol $\left(\mathrm{CH}_{3} \mathrm{OH}\right) 3.75 \mathrm{ml}$ of tetramethoxysilane (TMOS) were added, the resulting mixture was stirred for 5 min. Then $4.5 \mathrm{ml}$ of distilled water were added to the mixture which was again stirred. To increase the rate of hydrolysis, $0.525 \mathrm{ml}$ of hydrochloric acid were added. The mixture obtained was poured to Petri dishes of $35 \times 10 \mathrm{~mm}^{2}$ and sealed. The process of gel formation took $24 \mathrm{~h}$, followed by drying at $45^{\circ} \mathrm{C}$ during for 5 days. Annealing of the dried samples took place at $250^{\circ} \mathrm{C}, 500^{\circ} \mathrm{C}$ and $750^{\circ} \mathrm{C}$ with $60 \mathrm{~min}$ exposure at each temperature.

The samples obtained were transparent colorless disks with a diameter of $20 \mathrm{~mm}$ and a thickness of $1 \mathrm{~mm}$. Density and porosity of the silica matrices determined by the method of hydrostatic weighing were $1.40 \mathrm{~g} / \mathrm{cm}^{3}$ and 54 vol. $\%$, respectively. High value of porosity was obtained by careful selection of the ratio of reagents as well as the parameters of synthesis (gel formation, drying and annealing) and no extra additives were used. Average diameter of pores $(\sim 3.5 \mathrm{~nm})$ was determined by the method of nitrogen adsorption/desorption isotherms.

Second method of ZnSe nanocrystals obtaining (CVD method) includes the chemical reaction in the vapor phase over the surface of $\mathrm{SiO}_{2}$ matrix following by precipitation of the reaction product in the matrix. CVD tube furnace consisted of two zones: hot zone and cold zone. The first one was heated up to $800^{\circ} \mathrm{C}$, to this zone CVD ZnSe bulk crystal was placed. High temperature led to evaporation of $\mathrm{Zn}$ and Se atoms (in the form of separate atoms, not molecules). These atoms were deposited in the cold zone of the tube where silica matrix was placed. Deposition of $\mathrm{Zn}$ and Se atoms was accompanied by their interaction on the surface and within the pores of $\mathrm{SiO}_{2}$ marix followed by formation of ZnSe nanocrystals.

Luminescence spectra were obtained using spectrofluorimeter based on the grating monochromator, luminescence was excited by diode-pumped solid state laser with $\lambda_{\text {exc }}=457 \mathrm{~nm}$. Temperature was varied from $10 \mathrm{~K}$ to $300 \mathrm{~K}$ using ARS DE-204AE cryostat with LakeShore 335 temperature controller. 


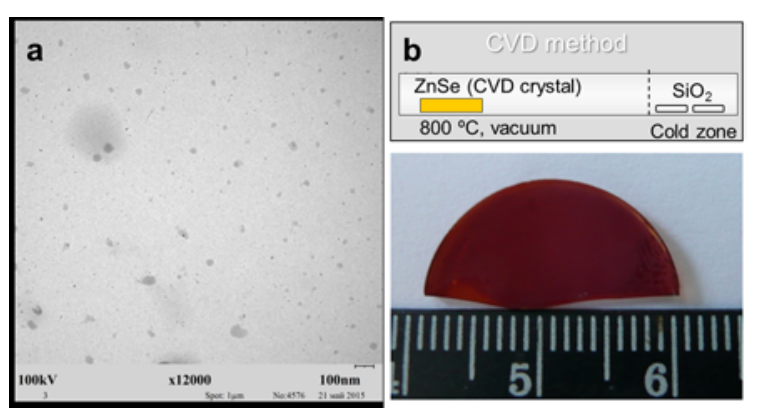

Fig. 1. a) TEM of ZnSe nanocrystals obtained by milling of ZnSe (CVD) crystal. b) Scheme of CVD method of ZnSe nanocrystals obtaining in silica pores and image of ZnSe nanocrystals obtained in pores of $\mathrm{SiO}_{2}$ matrix.

\section{Results and discussion}

TEM of ZnSe nanocrystals obtained by mechanical milling is shown in the Fig. 1a. The average size of nanocrystals was varied in the range from 90 to $250 \mathrm{~nm}$. Image of $\mathrm{SiO}_{2}$ matrix with $\mathrm{ZnSe}$ nanocrystals obtained by CVD method is shown in the Fig. 1b. Red tint of $\mathrm{SiO}_{2}$ matrix with $\mathrm{ZnSe}$ nanocrystals can be formed by excess zinc deposited on the surface of $\mathrm{SiO}_{2}$ matrix.

Luminescence spectra of bulk ZnSe crystal obtained by CVD method at $4 \mathrm{~K}, 77 \mathrm{~K}$ and $300 \mathrm{~K}$ are shown in the Fig. 2. Luminescence spectra at all temperatures contain wide band with maximum at $480-490 \mathrm{~nm}$. At $10 \mathrm{~K}$ the spectrum is more complex containing also an additional wide band with maximum at about $520 \mathrm{~nm}$ and a high number of narrow peaks ranging from 440 to $470 \mathrm{~nm}$ formed by nearedge transitions of free and bound excitons. More close investigation of the temperature dependence of $490 \mathrm{~nm}$ band for bulk CVD crystal shows that intensity of this band is close to zero already at $150 \mathrm{~K}$. Such a strong temperature dependence is typical for donoracceptor transitions with participation of electrons trapped by defect states and localized close to the edge of conduction band. Temperature quenching of luminescence is described by: $I=I_{0}\left(1+B e^{\{-E a / k T\}}\right)^{-1}$ (here $E_{a}$ is the activation energy which is determined by the gap between the bottom of conduction band and the level from which the luminescence occurs) allows determining the activation energy. The values of the activation energies $E_{a}$ (Fig. 2, inset) are different in the low and high temperature regions $(5 \mathrm{meV}$ and $280 \mathrm{meV}$, correspondingly). Value of activation energy in the high temperature region $(280 \mathrm{meV})$ is close to the difference between the bottom of conduction band (about $2.7 \mathrm{eV}$ ) and position of the level, from which $490 \mathrm{~nm}$

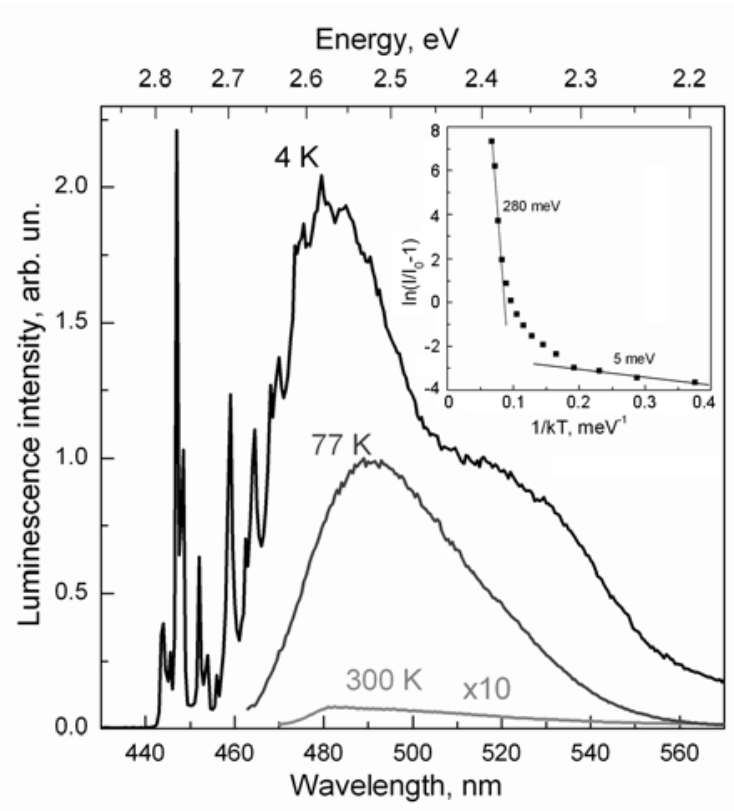

Fig. 2. Luminescence spectra of ZnSe bulk (CVD) crystal at $10 \mathrm{~K}, 77 \mathrm{~K}$ and $300 \mathrm{~K}$. In the inset - temperature dependence of luminescence intensity for ZnSe CVD bulk crystal in $\left\{1 / k T, \ln \left(I_{0} / I\right)-1\right\}$ coordinates.

luminescence originates (about $2.5 \mathrm{eV}$ if we suppose that recombination of trapped electrons occurs with the holes from the valence band). So, the supposition about participation of the bottom of conduction band in the quenching of green luminescence of $\mathrm{ZnSe}$ crystal seems plausible.

The luminescence spectra of ZnSe nanocrystals obtained after milling of $\mathrm{ZnSe}$ (CVD) crystal at $300 \mathrm{~K}$ and $10 \mathrm{~K}$ are shown in the Fig. 3.

At $300 \mathrm{~K}$ the luminescence spectrum consists of the wide complex band with maximum at about $380 \mathrm{~nm}(3.28 \mathrm{eV})$. This spectrum can be decomposed into two Gaussian bands with maxima at $480 \mathrm{~nm}$ $(2.62 \mathrm{eV})$ and $380 \mathrm{~nm}(3.28 \mathrm{eV})$. The first one corresponds to the green luminescence band observed in bulk crystal. As can be seen from Fig. 3a, temperature quenching of $480 \mathrm{~nm}$ band in ZnSe nanocrystals obtained after milling of ZnSe (CVD) crystal is less than for corresponding bulk crystal.

The second luminescence band $(3.28 \mathrm{eV})$ cannot be formed by transitions between any defect levels in the band gap of $\mathrm{ZnSe}$ lattice as the band gap of $\mathrm{ZnSe}$ is $\sim 2.7 \mathrm{eV}$, but position of this peak is close to the well-known green luminescence band of $\mathrm{ZnO}$ nanocrystals widely discussed in the number of papers [15-16]. ZnO is readily formed on the surface of ZnSe nanocrystals in air. 

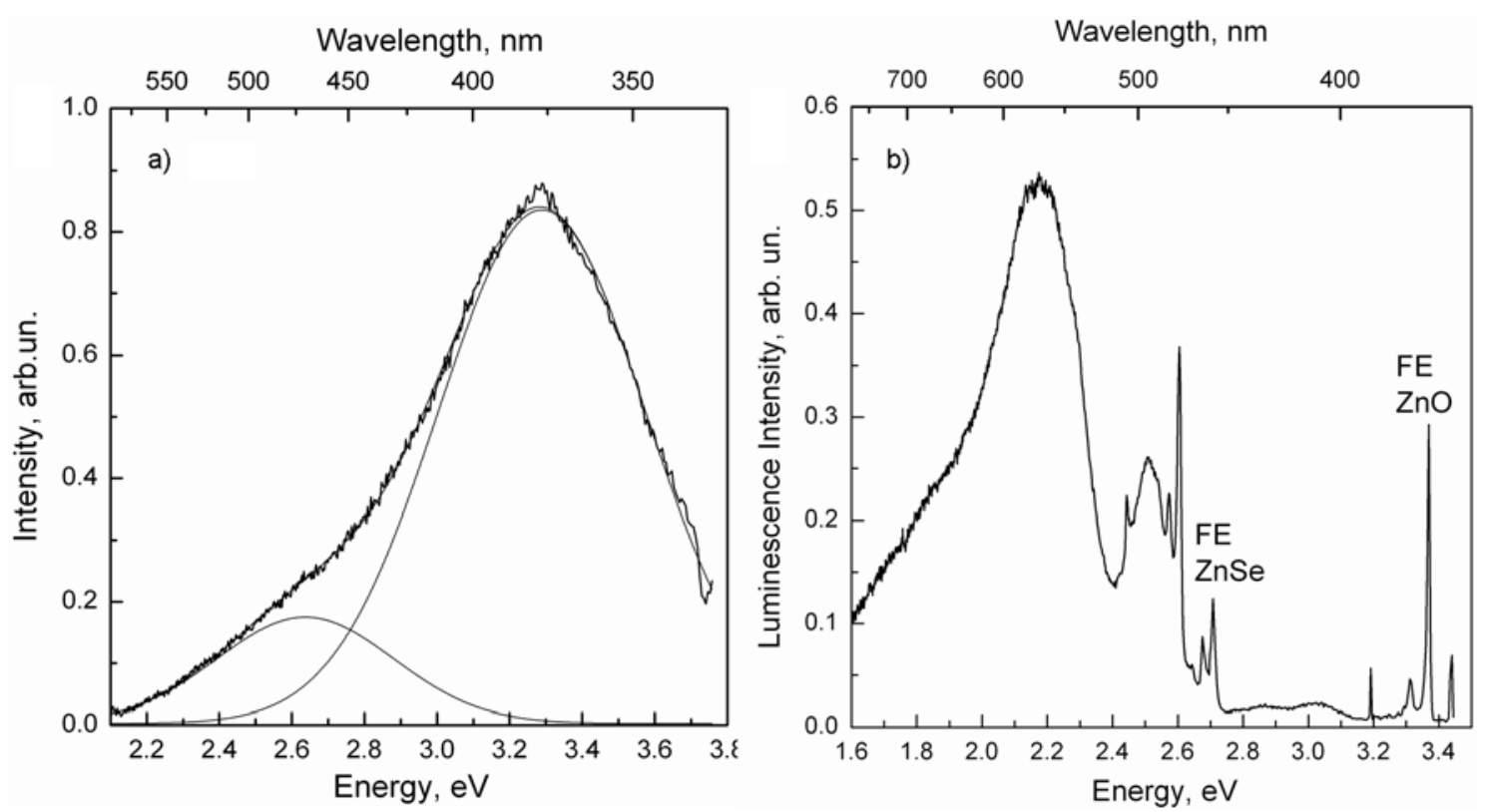

Fig. 3. Luminescence spectrum of ZnSe nanocrystals obtained by milling of ZnSe (CVD) crystal at $300 \mathrm{~K}(\mathrm{a})$ and $10 \mathrm{~K}(\mathrm{~b})$.

This assumption is clearly confirmed by luminescence spectrum taken at $10 \mathrm{~K}$. In this spectrum two distinct series of exciton transitions at $2.6-2.8 \mathrm{eV}$ and $3.2-3.4 \mathrm{eV}$ can be observed. The first series corresponds to the series of exciton peaks observed for ZnSe bulk crystal (Fig. 2), while the second one is typical for zinc oxide. So, mechanical milling of ZnSe bulk crystal leads to formation of nanocrystals with core formed by ZnSe, while its surface layer is formed preferably by $\mathrm{ZnO}$.

Oxidation of $\mathrm{ZnSe}$ surface with subsequent formation of surface $\mathrm{ZnO}$ layer can be prevented if nanocrystals are formed inside the pores of silica matrix. Also ZnSe nanocrystals with sufficiently smaller sizes determined by diameter of pores $(\sim 3.5 \mathrm{~nm})$ in silica matrix can be obtained.

As can be seen from Fig. 4a, band edge absorption of $\mathrm{ZnSe}$ nanocrystals in the pores of $\mathrm{SiO}_{2}$ matrix (Fig. 4a) is shifted to the higher energies as compared to absorption of the bulk ZnSe CVD crystal (band gap increases from $2.7 \mathrm{eV}$ for CVD crystal to $\sim 2.8 \mathrm{eV}$ for $\mathrm{ZnSe}$ nanocrystals in pores of $\mathrm{SiO}_{2}$ matrix). Increase of the band gap for nanocrystals is a direct manifestation of quantum size effect connected with the decrease of the size of nanocrystal. Dependence of the band gap of semiconductor nanocrystal on its size can be determined using the following approximate relation:

$$
E(R)=E_{g}+\frac{\hbar^{2} \pi^{2}}{2 R^{2} \mu}-\frac{1.786 e^{2}}{4 \pi \varepsilon_{0} \varepsilon R},
$$

where $E_{g}$ is a band gap of the bulk crystal, $R$ is the size of the nanocrystal and $\mu$ is a reduced mass of an electron and an hole [17]. Using the previously determined band gaps and taking the values of $\varepsilon$ and $\mu$ for ZnSe from the literature data [18], the average size of nanocrystals can be determined, which is equal to $\sim 3 \mathrm{~nm}$.

In the Fig. $4 \mathrm{~b}$ luminescence spectra of ZnSe nanocrystals obtained in the pores of $\mathrm{SiO}_{2}$ matrix by CVD method are shown. These luminescence spectra are complex and consist of two bands in the green region with maxima at about $500 \mathrm{~nm}$ and $530 \mathrm{~nm}$ that can be ascribed to the presence of two different types of electron-trapping defects and less pronounced band in the red region that has not been observed for different samples. Also the width of the complex band exceeds sufficiently the width of the luminescence band for bulk CVD crystal. Increase of the temperature from $77 \mathrm{~K}$ to $300 \mathrm{~K}$ leads to decrease of the intensity in only 1.4 times, so the processes of temperature quenching have very small influence on the luminescence of nanocrystals obtained by this method. Values of activation energies of temperature quenching (Fig. $4 \mathrm{~b}$ ) are $44 \mathrm{meV}$ and $5 \mathrm{meV}$ for high temperature and low temperature region, respectively.

Sufficiently different temperature dependences of luminescence intensity of green band for bulk crystal and nanocrystals allow supposing the different mechanisms of luminescence quenching in $\mathrm{ZnSe}$ 
Energy, eV
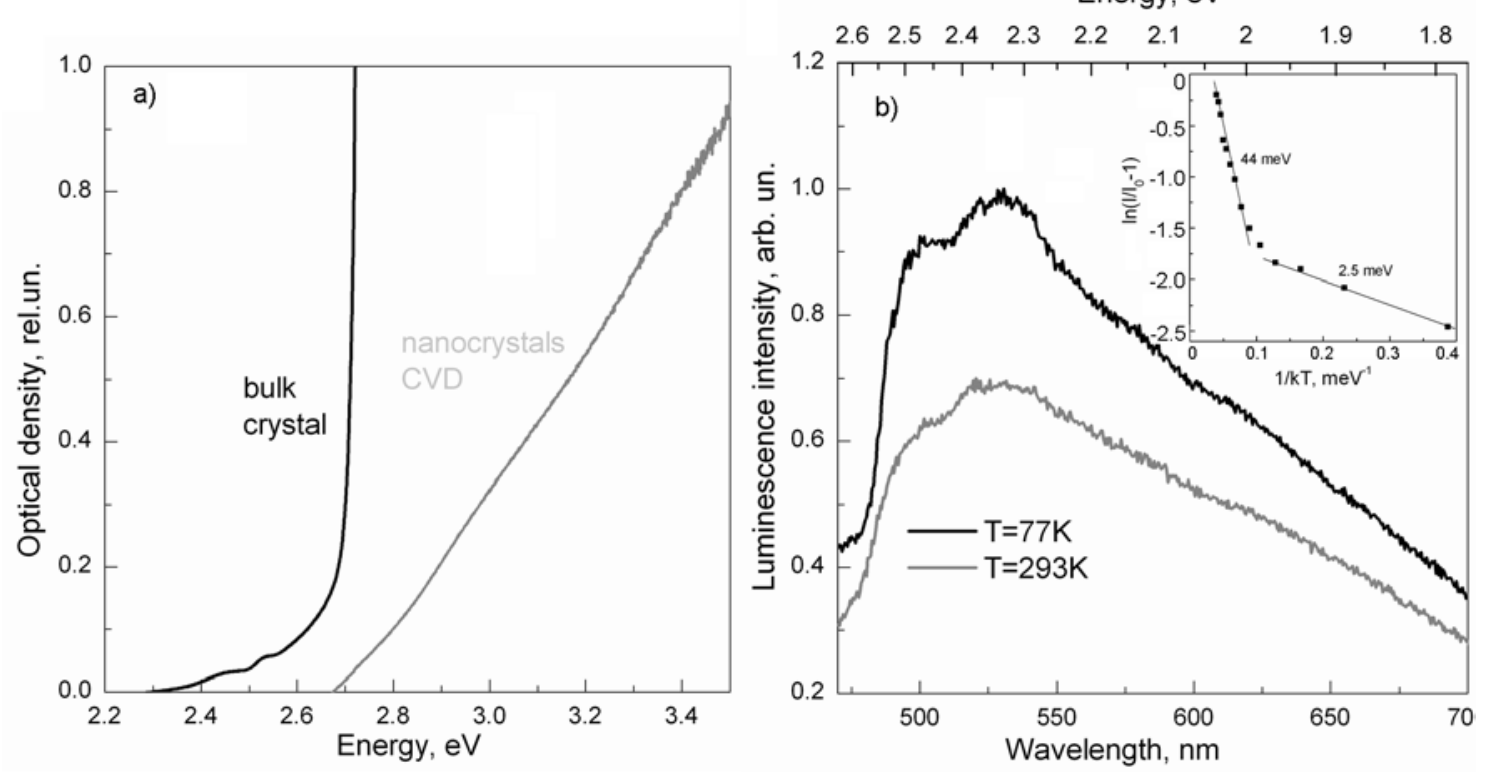

Fig. 4. a) Band edge absorption of bulk ZnSe CVD crystal and ZnSe nanocrystals in the pores of $\mathrm{SiO}_{2}$ matrix, b) Luminescence spectra of $\mathrm{ZnSe}$ nanocrystals in the pores of $\mathrm{SiO}_{2}$ matrix at $77 \mathrm{~K}$ and $300 \mathrm{~K}$. In the inset - temperature dependence of luminescence intensity for ZnSe CVD nanocrystals in silica pores in $\left(1 / k T, \ln \left(I_{0} / I\right)-1\right)$ coordinates.

bulk and nanocrystals. Analysis of decay curves [19] have shown that while for bulk crystal quenching of luminescence takes place with participation of the bottom of $\mathrm{CB}$, for nanocrystals becomes inefficient due to increase of the gap between the bottom of conduction band and the level, from which luminescence occurs. The same mechanism can be valid also for ZnSe nanocrystals obtained after milling of ZnSe (CVD) crystal.

\section{Conclusions}

ZnSe nanocrystals were obtained from bulk ZnSe crystal using two different routes: mechanical milling and heating of bulk crystal with subsequent deposition in the pores of silica matrix. For ZnSe nanocrystals obtained by mechanical milling formation of surface ZnO layer was determined. All samples demonstrate presence of green luminescence band at $\sim 500 \mathrm{~nm}$ which temperature stability is sufficiently higher for nanocrystals obtained by either of two routes than for correspondent bulk sample.

\section{References}

1. N.Zhao, T.P.Osedach, L.-Y.Chang et al., ACS Nano, 4, 3743 (2010).

2. J.Chen, J.L.Song, X.W.Sun et al., Appl. Phys. Lett., 94, 153115-3 (2009).

3. N.Tessler, V.Medvedev, M.Kazes et al., Science, 295, 1506 (2002).
4. V.I.Klimov, A.A.Mikhailovsky, S.Xu et al., Science, 290, 314 (2000).

5. C.Dang, J.Lee, C.Breen et al., Nature Nanotechnology, 7, 335 (2012).

6. M.Zhang, A.Banerjee, C.-S.Lee et al., Appl. Phys. Lett., 98, 221104-3 (2011).

7. Quantum Dots: Research, Technology and Applications, ed. by R.W.Knoss, Nova Science Publishers, New York (2008).

8. J.Drbohlavova, V.Adam, R.Kizek, J.Hubalek, Int.J.Mol.Sci., 10, 656 (2009).

9. W.C.W.Chan, S.M.Nie, Science, 281, 2016 (1998).

10. W.W.Yu, Expert Opin.Biol.Ther., 8, 1571 (2008).

11. R.Gill, M.Zayats, I.Willner, Angew.Chem.Int. Ed., 47, 7602 (2008).

12. S.Silvi, M.Baroncini, M.La Rosa, A.Credi, Topics in Current Chem., 374, 65 (2016).

13. P.Harrison, A.Valavanis, Quantum Wells, Wires and Dots: Theoretical and Computational Physics of Semiconductor Nanostructures, John Wiley \& Sons, New York (2016).

14. O.Viagin, A.Masalov, I.Bespalova et al., J. $L u$ minescence, 179, 178 (2016).

15. K.Vanheusden, W.L.Warren, C.H.Seager et al., J. Appl.Phys., 79, 7983 (1996).

16. K.Vanheusden, C.H.Seager, W.T.Warren et al., Appl. Phys. Lett., 68, 403 (1996).

17. L.E.Brus, J.Chem. Phys., 80, 4403 (1984).

18. J.Gutowski, K.Sebald, T.Voss. ZnSe: Dielectric Constants. In New Data and Updates for III-V, II-VI and I-VII Compounds, Springer Berlin, Heidelberg (2010).

19. A.A.Masalov, V.V.Seminko, N.V.Kononets et al., J. Luminescence, 181, 337 (2017). 